19 Revue d'histoire du XIXe siècle

Société d'histoire de la révolution de 1848 et des

révolutions du XIXe siècle

15 | 1997

1818. Nouveaux regards

\title{
1848. Nouveaux regards
}

Jean-Claude Caron and Michèle Riot-Sarcey

URL: http://journals.openedition.org/rh19/116

DOI: $10.4000 /$ rh19.116

ISSN: $1777-5329$

Publisher

La Société de 1848

\section{Printed version}

Date of publication: 1 December 1997

ISSN: 1265-1354

Electronic reference

Jean-Claude Caron and Michèle Riot-Sarcey, «1848. Nouveaux regards », Revue d'histoire du XIXe siècle [Online], 15 | 1997, Online since 10 September 2008, connection on 01 May 2019. URL : http:// journals.openedition.org/rh19/116 ; DOI : 10.4000/rh19.116

This text was automatically generated on 1 May 2019.

Tous droits réservés 


\section{Nouveaux regards}

Jean-Claude Caron and Michèle Riot-Sarcey

\section{ABSTRACTS}

No abstract available by now

Pas de résumé disponible actuellement

INDEX

Mots-clés: 1848 